\title{
Is the Public Private Partnership Model the Right Vehicle for Public Infrastructure Delivery in Developing Countries?
}

\author{
Patrick Mabuza \\ African Development Bank, Abidjan, Ivory Coast \\ P.Mabuza@afdb.org
}

\begin{abstract}
There has been an increase in the number of governments that adopted public-private partnership (PPP) as an infrastructure delivery model. However, there are still misgivings about the role PPPs play in developing countries' economies. The objective of this study is to address the question of whether the PPP model really benefits the public. This study follows a qualitative approach based on international review of literature on PPP experiences around the world. The results of the study indicate that, the PPP model can be a good vehicle for delivering public infrastructure projects in developing countries. However, for PPPs to meet the expectations of the public sector and the citizens there are certain aspects that need to be in place i.e. transparency, accountability, optimum risk allocation/sharing, and increased competition to name just a few. If a country implements its PPP programme properly, there are massive benefits compared to the public procurement approach that may accrue to consumers and the economy as a whole. Such benefits include reduced prices, which may also increase access to services. The study has elucidated valid from invalid arguments about PPPs and has established whether the PPP model is indeed the right vehicle for delivering infrastructure projects.
\end{abstract}

Keywords: Public-private partnership models, traditional public sector procurement approach, concessionaire, private party, cost overrun and efficiency.

\section{Introduction}

The increasing need to stimulate economic growth, sustainable development, boost public health, transport, school and safety have led to infrastructure requirements far in excess of currently available financing resources (OECD, 2006 and Quiggin, 1996). The increase in demand for infrastructure services has put a lot of pressure on governments to increase investment in infrastructure (De Bettignies and Ross, 2004). This pressure was worsened by the 2008 financial crisis. Meeting this ever-increasing pressure for infrastructure investment is imperative to reducing the negative impact that it may have in terms of economic growth and development in the long term. As a response to this increasing pressure to provide more and better services to citizens albeit limited budgets, governments have adopted innovative infrastructure delivery mechanisms such as PPPs to deliver the needed public services (Urban Land Institute, 2005; Harris, 2003; De Bettignies and Ross, 2004). There are two schools of thoughts about the role that PPPs can play in developing countries' economies. On the one hand, there are those who argue that PPPs are good because they enable governments to deliver needed infrastructure even if they do not have the budget to do so. It is further argued that PPPs can deliver infrastructure at lower costs due to economies of scale (Moszoro, 2010). On the other hand, they are those who argue against using the private sector to deliver public services (Vining, Boardman \& Poschmann, 2004 and Hall, 2015).

Their arguments are that, (i) PPPs are as good as privatisation, (ii) Procuring infrastructure through PPPs is more costly compared to traditional procurement, (iii) PPPs are weak in accountability and transparency, have negative impact on public-sector jobs, lack flexibility and that private companies result in service quality shading in pursuit of profits (McDavid and Clemens, 1995). In contrast to these arguments, those who support PPPs argue that the criticism against PPPs tend to be over-simplified or tell only part of the story. In Africa, PPPs have a presence in the following sectors: water, roads, prisons, energy, government office accommodation, nature reserves, hospitals, tourism to name a few. In South Africa, two PPP approaches or models are currently implemented. Under the first approach (the traditional PPP), the private sector design, finance, construct, operate and maintain the infrastructure asset. An example of where this approach was used in South Africa is N4 and the N3 concessions. The second approach is a hybrid of the traditional PPP and public procurement approaches. The South African National Roads Agency Limited (SANRAL) adopted this 
approach when procuring the Gauteng road expansion project. Under this approach, the government raises funds to finance the project and the private sector partner provides expertise. Both approaches have their own pros and cons, for example, when the traditional PPP approach is used, government or its agency has limited control on how the project should be implemented as the private sector party has full control of the project.

However, under the hybrid approach, the government's agency retains some influence on how the implementation of the project should be carried out as it carries most of the project's risks. The objective of this paper is, therefore, to discuss in detail the arguments for and against PPP projects with the aim of elucidating valid from invalid arguments about PPPs and to establish if the PPP model is indeed the right vehicle for delivering infrastructure projects in developing countries. The paper is organised as follows: section 2 discusses material and methods while section 3 discusses the study research method, section 4 discusses the study results and section 5 gives conclusion and recommendations.

\section{Material}

PPPs and Economic Development: Investment in infrastructure is imperative for economic growth and development. Infrastructure availability and quality influence a number of decisions related to private sector investment, migration, and other social related decisions (United Kingdom Department for International Development, 2007). Although a lot of research on the relationship between infrastructure and development outcome have been undertaken, the link between these two is still a topic for debate among economists (Snieska and Simkunaite, 2009). A number of empirical studies, such as those conducted by Rives and Heaney (1995), Bafoil and Ruiwen (2010), Kim (2006), Munnell (1992), Yoshino and Nakahigashi (2000), and Boopen (2006) found a strong link between infrastructure availability and economic development; hence infrastructure delivery is a high priority for governments. In the past, public infrastructure delivery was the sole responsibility of the public sector; however, this has now changed as infrastructure delivery is also provided by the private sector, mainly under the PPP arrangement.

Grimsey and Lewis (2005), define PPPs as an arrangement whereby a private party participates in or provides support for, the provision of infrastructure-based service, and such an arrangement results in a contract for a private entity to deliver this infrastructure-based service to citizens. According to the Republic of South Africa's National Treasury (2004), a PPP is, “... a contract between a public-sector institution and/or municipality and a private party, in which the private party assumes substantial financial, technical and operational risk in the design, financing, building and operation of a project". There are a number of partnership models used to deliver public services. On one side of the spectrum, the public sector retains almost all responsibilities in the partnership and carries all the risks associated with the project. On the other side, the private sector carries all the risks and responsibilities associated with the project. PPP projects, therefore, fall into the middle of the spectrum, between the public sector and its private partner according to their strength and weaknesses. Figure 1 below depicts a full spectrum of a PPP structure and the level of private sector participation in a PPP project.

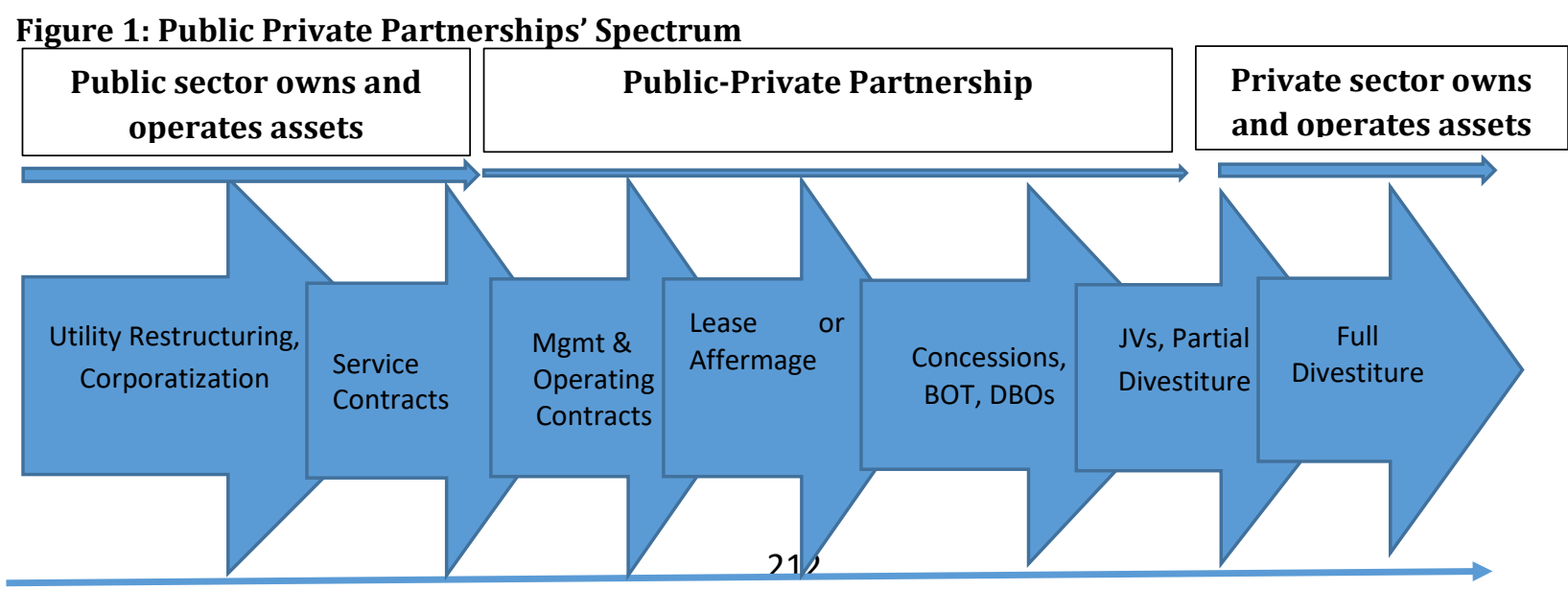


It can be deduced from Figure 1 and the above definition that, PPPs are expected to deliver high-quality services by taking advantage of the fact that in such arrangements one can draw from the best of the public and private sector's expertise. Indeed, according to Binza (2008), at the heart of every successful project is the concept that better value for money may be achieved through the exploration of private-sector competencies and the allocation of risk to the party best able to manage it. Under the traditional PPP model, the private sector carries more responsibilities than the public sector compared to when the traditional public sector procurement method is used. PPP proponents argue that the foundation of PPPs is the ability of the public sector to be able to contract-out some of the services that are traditionally provided by the public sector. Such an argument is inspired by the belief that contracting-out with the private sector results in reduced service costs and provides a better quality of service compared to public provision. This argument is centred on ex-ante competition, high-powered incentives, optimal risk allocation and economies of scope and scale. These claims are a subject of discussion in this study.

\section{Methods}

The approach followed in this study entails a detailed assessment of international, continental, regional and local literature. The analysis focuses on PPPs for large infrastructure projects, their success, failures and lessons learnt. The information collected from the international PPP experiences has been used to support or not to support the divergent views on whether PPPs have or have not benefited the public in developing countries. The method used is justified because there is already a lot of literature that exists on this topic, but there is no research that has used the available literature to answer the question of whether the PPP model has really benefited the public?

\section{Results}

As mentioned earlier, the objective of this study is to use evidence from international literature to assess whether the PPP model has really benefited the public. This section, therefore, focuses on the different arguments about the usefulness of PPPs in addressing socio-economic challenges faced by different countries.

Arguments for and Against Using PPPS as a Vehicle to Deliver Public Infrastructure Projects: This section discusses both economic and non-economic arguments about using PPPs. The rationale for governments to undertake PPPs can be summarised into three broad arguments; namely: (a) minimisation of on-budget government expenditure, (b) to deliver both infrastructure and services at a lower cost due to economies of scale, scope, and (c) makes it easy to impose user fees, and avoid increasing government expenditure (Vining and Boardman, 2006). However, some economists argue against using the private sector to deliver public services.

Economic Arguments for Using PPPs: Following below is a discussion on the economic arguments for using PPPs.

Does the Use of PPPs Minimise On-budget Government Expenditure: PPP opponents argue that PPPs help governments to hide infrastructure capital expenditure by keeping it off the government's official balance sheet (Hall, 2015). Vining and Boardman (2006), argue that hiding capital expenditure in this way carries some political benefit because government budgets will always appear healthy in the face of the voters. While a significant amount of tax is used for PPPs. Engel et al. (2013), also support this argument in that, PPPs have negatively affected governments' balance sheets in many countries such as in the United Kingdom, Portugal, Chile, and Peru. In the United Kingdom, evidence shows that 717 projects in the Private Finance Initiative (PFI) would require a fiscal outlay of between $£ 10$ billion annually until 2020 to pay capital costs. Portugal also realized that it must divert about 1\% of its GDP to pay for its PPP commitments until 2015 and in Chile, the government realized that its maximum exposure to PPPs was around 4\% of GDP, while the expected value from the PPP highway project was only $0.2 \%$. Contract renegotiation is another challenge that increases the amount that governments have to pay for PPP projects and that raises concerns about the validity of the PPP model. 
For example, according to Guash (2004), the fiscal cost of contract renegotiations as a percentage of initial investment value reached $20.3 \%$ in Chile and $26.5 \%$ for Peru and over 41 percent of infrastructure concessions in Latin America and the Caribbean have been renegotiated. The argument about minimizing government expenditure may be true in a case where the government pays the PPP project firm for the services rendered and that may increase governments' expenditures related to PPP projects. However, this may not be the case in instances where the private party funds PPP projects and the money invested in constructing the asset is recouped from user tariffs. In such a case, this argument does not hold. Vining, Boardman \& Poschmann, (2004) argue that PPPs conceal government debt; therefore, PPPs should not be considered for their potential to generate value for money, but merely as a remedy for cash-strapped governments. It is important to note that other countries especially in the developed economies such as the United Kingdom and in the developing world such as South Africa, do record all costs related.

PPP projects in their Medium-Term Expenditure Frameworks (MTEF, Republic of South Africa National Treasury, 2007). The concealing of debt argument may not be true in all cases. However, the remedy for the cash-strapped government argument may be true. In fact, that is what governments should do, instead of introducing new taxes to fund such projects they should use private capital. Nevertheless, the renegotiation of concession contracts does pose a risk for governments as this has the potential to make PPPs expensive compared with the traditional procurement model. Hall (2015) further argues that PPPs have worsened fiscal problems as evident in countries that made the greatest use of PPPs in the past decades, such as Spain and Greece. He may be underestimating the fact that the fiscal problems faced by these countries may not be solely as the result of PPP projects but may be due to other factors such as macroeconomic policies and political climate faced by these countries.

The effect of PPP projects on the country's finances is also dependent on how the PPPs are structured and managed and how renegotiations of PPP concessions are handled. Where these issues are handled properly and corruption is dealt with decisively, PPPs will not lead to fiscal problems but may help reduce such problems. Based on the above arguments it can be concluded that the opportunity cost argument makes a lot of economic sense while the minimisation of on-budget government expenditure argument is a weak argument because there are other ways that governments can use to minimise government capital expenditure other than using PPPs. The opportunity cost argument is true in that; if the government does not provide the service to consumers because it does not have the money for the project, there would be opportunity costs involved in the economy as a whole. Therefore, there is a strong case to have the project or service provided by the private sector rather than not having it at all.

Are Services' Unit Costs Lower When Provided by PPPs: There are three perspectives to PPPs' costsuperiority argument; namely: (i) Economies of scale argument: Private-sector firms are believed to have economies of scale, scope or learning, compared to the public sector, which usually has less experience with the relevant technology or activity (Bloomfield, 2006). (ii) Learning economies: Given the fact that larger private firms engage in a more similar project, that are global in scope. This gives them exposure to international best practices and helps them utilize learning economics, which is not the case with most governments, which engage in a limited number of projects (Vining et al., 2004 and Moszoro, 2010). Early empirical studies supported this argument and showed that the logarithm of unit cost decreases with the logarithm of a cumulative number of units produced at a uniform rate-the learning rate (Lapre \& Van Wassenhove; 2003). This means that the more a firm produces a certain service, the more it benefits from learning economics. (iii) Superior incentives to reduce costs: The private sector has superior incentives to minimise costs, holding all constant, because of the cost-reduction profit incentives build in its business model. Such incentives include but not limited to giving share options and bonuses to senior management including staff members (Vining et al., 2004). As a result, the private sector has a greater incentive to invest in cost-reduction measures ex-ante in order to provide the service at a lower cost that will lead to higher profits. Since PPPs allow bundling up various components of a project and transferring them to a single contracting party.

Therefore, PPPs force the contracting party to focus on the total life-cost of the asset by implementing costefficient operational approaches or measures through the project's life cycle. Such measures include good 
procurement policies and hiring personnel with good project management expertise (Gabriel and Head, 2005). The dimension of superior incentives by private firms to reduce costs is supported by empirical studies. For example, Domberger and Rimmer (1994) reviewed about twenty studies that looked at competitive tendering and contracting (CTC) and concluded that there is broad consensus that CTC leads to a substantial reduction in service costs (Globerman and Vining, 1996). However, those who are against CTC argue that the observed cost savings are a result of decreased service quality not because of improved efficiency. Studies conducted in the United Kingdom and Australia for different years confirmed these private firms' efficiencies. They revealed that if a project is implemented by a private firm, the magnitude of costs savings are around $22 \%$ on average, and approximately $80 \%$ of all PPP projects are delivered on time (see Gabriel and Head, 2005; Domberger and Jensen, 1997, Boardman et al., 2009; King, 2001). It is worth noting that these studies support the private-sector efficiency argument based only on financial benefits. When other factors such as transaction costs, costs associated with contract negotiation and costs associated with the government's administration of the tender are taking into account, the efficiency superiority of private firms become questionable. For example, recent studies on the cost savings of PPP projects have disputed these findings and concluded that when these costs are taken into account, the savings decrease even further (Domberger and Rimmer, 1994).

The differences in the findings may be exacerbated by the fact that the projects being compared have different legal structures, come from different economic sectors, different legal jurisdictions, operate under different political environments, therefore a comparison of such projects may give inaccurate conclusions. Arguments for, or against, PPPs should take into account the fact that once a service is provided by a private firm, there are a lot of changes that take place, which makes it difficult to compare efficiencies before and after a private provision of a service. Such comparisons are complicated by the fact that public-sector accounting methods rarely capture the full economic costs of service provision (Domberger and Jensen, 1997) and the fact that contracting brings with it changes in the specification of service requirements and quality. Therefore, comparison of the price of a new private-sector service contract with the historical costs of public provision may be misleading, as data on similar costs are normally not available. It is also important to note that private sectors' cost advantages might not be true in all circumstances, as some government departments may be more efficient than some private firms. Therefore, such comparisons may be true only if one considers only the financial benefits and not the overall economic benefits that also take into account project externalities.

Is Borrowing Costs Low for the Public Sector Compared to the Private Sector: Those against PPPs argue that PPP are expensive as they come with a higher price tag compared to traditional procurement because their borrowing costs are higher than governments' borrowing cost? However, those who support PPPs disagree with this assertion and argue that such statements are based on three convictions that do not hold water when tested against economic principles. The first conviction is that the public sector borrows at a cheaper rate than the private sector. This argument is based on the belief that government borrowing is backed by tax revenue and is considered to be risk-free, which leads to low government borrowing costs compared to private-sector borrowing. PPP proponents further backed-up this assertion by the fact that government bonds carry a lower interest rate than corporate bonds (Klein, 1996). However, this argument is challenged by Currie (2000), and argues that when a project is funded by the private sector, investors carry the risk of default and are rewarded accordingly, whereas when funded by the public sector, taxpayers carry the risk but are not compensated for doing so. If taxpayers' compensation is taken into account, the borrowing cost advantage of the public sector may be insignificant or may not exist at all.

Even though the public sector can borrow cheaper to finance investment projects, however, it worth noting that this imposes a residual risk on taxpayers in much the same way as private-sector investors but without rewards. It is, therefore, imperative to consider this liability being imposed on taxpayers as a cost that should be accounted for in any cost-benefit analysis of a project. The second conviction is that, when an investment is made by the private sector, the private sector requires a rate of return that may be higher than what the public sector requires. This exacerbates the concerns that the financial benefits that accrue to the private sector will be more generous relative to the public-funded model; therefore; the borrowing cost advantage of the private sector may not benefit the public. The last conviction is that PPPs involve high up-front 
transaction costs (bidding costs and lengthy bidding processes) incurred by parties to prepare for the bid, and all these increases the cost of the PPP project. The time required negotiating a commercial agreement and the on-going costs of over-sight hinder competition in the PPP market and put a number of private players off, especially SMEs that, in turn, leads to expensive public services if provided through PPPs (Corry, 2004). It is clear from these arguments that the assertion that public financing of projects is cheaper than private financing is not convincing, especially when all costs associated with the project are taken into account.

Klein's argument that government's borrowing is cheaper because the public sector can raise money easily through taxes should it face financial difficulties, makes more sense only if one ignores the cost of underwriting the debt by citizens (Klein, 1996). As argued by Currie (2000), the citizens or the public underwrites or acts as a guarantor for government loans and receives nothing in return for playing that role, therefore, comparing government's borrowing with private sector borrowing may be misleading if the costs of underwriting the project by the citizens is not accounted for in the cost-benefit analysis. The public sector borrowing costs' advantage is also questionable if one considers governments in countries where there are high political risk, poor public finance management standards and poor tax collection mechanisms. One would find that such countries borrow at a higher interest rate than private-sector firms that have a healthy balance sheet. The argument that governments borrow at cheaper costs than the private sector is only true if one assumes a government with a healthy balance sheet, operating in a politically stable environment and ignore the risk carried by the citizens for underwriting governments' loans.

A convincing argument about the cost advantage of using PPPs is the one advanced by Moszoro (2010). According to Moszoro, the cost savings in a PPP, especially a hybrid PPP arrangement are possible because the SPV achieves optimal capital structure. This is so because, if the cost of capital is lower for public entities (all things equal) and the outlays on building the infrastructure are lower when the investment is made by a private sector, it is possible to reach the lowest total cost of constructing the asset with both public and private capital as part of the shareholding. This is because mixed capital structure enables internalization of both the cost of the capital advantage of the public sector and the knowledge advantage of the private sector. This shows that PPPs have the potential to deliver services at lower costs compared to the traditional approach, however, the allocation/sharing of risks within the SPV is fundamentally important.

Do PPPs Allow Private Firms to Sacrifice Quality for Profits: The main concern for the public or those that are against PPPs is that, the private sector trades-off quality of service for the sake of profits once a private company is awarded a PPP contract (Corry, 2004; Dudkin and Valila, 2005). This argument is not supported by international studies that compared service quality before and after service is contracted out to a private firm. These studies found that it is difficult to make a comparison on service quality after and before a service is contracted out because of non-availability of data on service quality prior to contracts being let. Domberger and Rimmer (1994) examined the quality argument in a sample of 61 cleaning contracts and concluded that, while competition lowered contract prices by between 35 to 50 per cent, cleaning performance was maintained and even enhanced in some instances. Alcazar, Nakasone \& Torero (2007) also evaluated the impact of private versus public provision of electricity in Peru using data from a 2005 survey. Their analysis concluded that the management of electricity by the private sector led to a significant improvement in the quality of service. Although these two studies made positive conclusions on the quality of service after contracting out, however, there remain questions about the reliability of data used as service quality data are normally not collected while the service is provided by the public sector.

A study by Domberger and Jensen (1997) that focused on quality shading after contracting out a service summarised a number of studies based on 40 English local authorities and concluded that contracting had led to major changes in the monitoring of services by government. The study found that contracting out the allowed the introduction of explicit inspection processes and implementation of clear performance standards. This implies that if quality deteriorates following contracting, that could be a problem of contract design or implementation, which is not associated with PPPs and can be prevented by applying appropriate output specification measures. Quality shading can happen if the public sector fails on its responsibilities of performing its oversight functions (Monga, Mahta \& Ranja, 2009). Another study by Domberger and Rimmer (1994) which summarised findings from ten studies that looked at the impact of contracting out on service 
quality, concluded that there is no consensus about the impact of contracting out on service quality. This is because all these studies suffered from data availability and quality problems. Given these findings, it is clear that the argument about quality shading is a matter that needs further research. An interesting argument is the one advanced by King (2001). King argues that a decline in quality accompanied by a fall in price may be socially desirable, particularly if the quality of the service being provided by the public sector was unnecessarily high for the recipients in question.

Is Project Risks Managed better in a PPP model than in the Traditional Procurement Model: PPPs proponents assert that PPPS enable governments to shift project risks from taxpayers to the private firm? This argument is based on the belief that the public sector can reduce risks associated with its financial exposure to construction costs, maintenance costs and demand risk by employing PPPs. This is due to the fact that the private sector managing the PPP project has the advantage and ability to spread risks of a project over a number of other similar projects because it normally engages in many similar projects simultaneously (Yescombe, 2007). This argument supports the assertion that private firms benefit from economies of scale and scope. This means that the private sector can manage risks much better than the public sector, given its experience in project management, construction and operation gained locally and from other jurisdictions (Gabriel and Head, 2005). The argument about shifting the project's risks from the public sector to the private sector as a reason for using PPP as argued above is weak and should be rejected. An economic activity that makes economic sense is the one that maximises the welfare of citizens, not the one that shifts or spreads risks from one economic agent to another. Spreading risks from the government to the private sector does not maximise the welfare of citizens, therefore should not be used as an economic justification to use PPPs as an alternative to the traditional procurement method.

As Allen (2001) asserts the main goal of risk sharing is not to maximise the amount of risks transferred from one party to another but is to reduce the overall risk in the economy. Therefore, any risk management strategy should seek to achieve this objective and that should be the objective of PPP projects. Using PPPs to deliver public services has some benefits because the private sector employs highly skilled risk managers and best risk management tools compared to the public sector and that reduces the overall risk of the project (International Monetary Fund, 2004, European Commission, 2003; Sadka, 2007). The reason why the private sector has an incentive to reduce project risks is because, should the risk eventuates, its profits will be negatively affected. It can, therefore, be argued that the low cost and price of services provided through PPPs is due to better risk management, optimal risk allocation and an optimal capital structure rather than risk shifting from the public to the private sector.

Non-Economic Arguments: This section discusses the non-economic arguments for using or not using PPPs.

Does the Use of PPPs Allow Governments to Avoid Accountability: Operating the asset and providing the service is the public face of a PPP project that a government in power would want to keep. What is of concern to governments when the private sector party in a PPP project is given the responsibility of providing a public service, is the loss of control associated with giving the private party certain contractual rights (De Bettignies and Ross, 2004). According to Fourie and Burger (2000) giving the control of the asset to the private party leads to loss of day-to-day democratic control of the project and accountability. This limits the public sector's flexibility to respond on time should the project face challenges that need immediate government's interventions. Before such interventions could be implemented, the state will need to first discuss with the private partner before it can take the necessary actions. The lack of flexibility by the state may negatively affect its effectiveness in dealing with concerns related to the project and that may negatively affect the government's public image. PPP opponents argue that, once a private partner takes over the responsibility of delivering a public service, accountability to elected public officials is lost and the public finds it difficult to hold these officials accountable as they hide behind the PPP firm (TD Economics, 2006).

What makes it even difficult is that, private sector's business practices are geared towards profits, which could be in conflict with government's goal of a high level of transparency, accountability and open public scrutiny. Such practices do not bode well with the private sector whose objective is to remain competitive by keeping its operation confidential. This concern stems largely from not understanding the difference between 
responsibility and accountability. The two are different in that: when a public sector transfers some responsibilities to the private sector, it does not relinquish accountability. Accountability always remains the responsibility of the public sector, regardless of the method used to deliver the service. According to Domberger and Jensen (1997), contracting can actually enhance accountability in three different ways, namely (a) by prompting reviews of standards and service specifications; (b) by introducing rigorous performance monitoring measures; and (c) by setting up mechanisms for redress in cases individuals or organisations have suffered loss or damage. Should there be a loss of accountability during the project's operation that would not because the project is a PPP, but because the public sector has neglected its responsibilities.

Do PPPs make it Easy to Impose User Fees Compared to When the Service is Provided by the State: According to Vining and Boardman (2006): “... governments believe or at least want to believe that privatesector operations make it politically more feasible to impose user fees, resulting in lower net expenditures for governments". The argument stems from the belief that users (or potential voters) would not have a problem paying for services provided by the private sector because of the understanding that the private firm needs revenue to cover its costs, repay its debt or make a profit. However, they will not accept a public sector charging them for services that, according to their understanding should be provided by the state free. As Vining and Boardman (2006) argue, this argument does have economic justification, especially when there are marginal social costs from public use, for example, when highways are tolled to prevent overuse. However, the public can still refuse to pay for the services as it happened with the Gauteng road improvement project ${ }^{1}$, where the public complained about the toll being too high. As a result, the public challenged the government through the courts and the implementation of the user fees was delayed by several months (Serrao and Flanagan, 2011).

A similar incident also occurred in Australia, where the West Gate Bridge was tolled, but due to public pressure, the tolls were removed (the United States of America, Department of Transportation, 2007). Regarding South Africa's case, Brits (2010) articulated clearly that some of the resistance by the public to pay for the tolls was due, to lack of information about the concession agreement and that impacted negatively on user perceptions about PPPs. This implies that improving transparency as well as information availability and accessibility about PPP agreements to potential users is imperative for PPPs to succeed. Information about PPPs' contribution to socio-economic issues like development of SMEs, employment, and the opportunity costs of not having the asset when it is needed can help ease public resistance to pay tolls.

Have PPPS Really Benefited the Public: According to Hall (2015), the UK government claims that 76 percent of PFI projects are completed on time compared with only 30 percent of traditionally procured projects. Another empirical study by Boardman, Laurin, Moore \& Vining (2009) concluded that the privatisation of the Canadian National Railways generated welfare gains of about $\$ 15$ billion. An evaluation by the European Investment Bank (EIB) on PPP projects that it funded came to the same conclusion that, PPP projects were largely completed on time, on specification and on budget (Hall, 2015). With regards to costs of PPP projects, an empirical study by Blanc-Brude; Goldsmith; and Valila (2006) of the EIB, concluded that PPP projects were 24 percent more expensive than public sector road projects. This percentage is of a similar magnitude as the cost overruns typically observed in traditional public procurement in the European road sector. This means that the costs associated with the traditional approach eventually match those of PPPs. Experience in the UK had also shown that, on costs, PFIs performed less well than traditionally procured projects. Although this finding may be true especially in developed economies, given the fact that developed countries' public sector employees may be well skilled and experienced to the level of private sector's employees. Should this be true, the efficiency advantage that PPP projects are believed to have over traditionally procured projects may not exist in developed economies. However, this may not be the case in developing countries where lack of appropriate skills and project management expertise are a challenge.

\footnotetext{
${ }^{1}$ The Gauteng roads improvement project is a project that aimed at improving the conditions of all National roads around the Gauteng Province of South Africa using the PPP model.
} 
However, the studies do not tell us as to which PPP model was used to procure these projects, the hybrid or the traditional PPP model? Furthermore, it is not clear from these studies whether the evaluations also took into account the optimal capital structure of a PPP project or not or it was based on basic comparison of projects that had different characteristics, operating within different legal frameworks, and with different contractual structures as all these may have a significant impact on the comparisons' results. According to a study conducted by Ismail, Mabuza, Pillay and Xolo (2014) on selected infrastructure projects including PPPs in South Africa showing their associated costs and time overruns showed that project costs in South Africa overran between 21 and 1329\%. Although there were only three PPP projects in the sample of 10 projects, two of the PPP projects showed low percentages of cost overrun. Normally high costs overrun for PPP infrastructure projects, in general, is caused by changes in project scope which were the main reason why most of the projects' had costs overrun in the South African's case, (South African National Roads Limited, 2012). It was difficult to tell whether PPP projects had low costs overrun in general or not given the limited number of PPP projects in the sample and the fact that all these projects were from different sectors and had different contractual structures. What makes it even more difficult to conduct a proper evaluation is that data on projects initial budgets and final project costs are hardly made public in most countries.

Based on the author's knowledge, there is no cross-sector study, which empirically determined whether the PPP model is the right vehicle for procuring public infrastructure projects. However, in the South African electricity industry, using data from the renewable energy independent power project procurement programme (REIPPPP) it is possible to show the benefits of PPP projects. When the programme started in 2011, the prices of electricity for the different renewable energy technologies were high. When the second bidding program was concluded some prices for the same technologies had decreased by up to $40.4 \%$ compared with the first bidding round. The third bidding round even saw more reduction in prices of up, to 68\% (Eberhard, Kolker, Leigland, 2014). There is no doubt that consumers and the economy as a whole benefited immensely from this programme in terms of lower energy prices. To evaluate whether PPPs are more efficient than traditional procurement is not an easy task. The European Investment Bank (2005) attempted to do this comparison and concluded that such an evaluation/comparison is difficult to make because it needs identification of two projects of similar specification, constructed and operated in the same legal, financial and fiscal framework and subject to the same market conditions. These requirements proved to be very difficult to meet.

\section{Conclusion and Recommendations}

From the above discussion, it is clear that there are differing views about the benefits that PPPs may render to the public. The discussion on these arguments will continue for a while until comprehensive and comparable data (or projects) on PPPs becomes available that will allow proper evaluation of PPP projects to determine their worth to the public. To say whether a PPP model is the right procurement model for infrastructure delivery for a country or not depends on how a country approaches the implementation of its PPP programme and whether it has the required expertise to drive the implementation of a PPP programme to achieve its objectives. If the PPP program is designed in a way that incentivises PPP participants to be efficient in financing, constructing and operating the project, such as the PPP model (hybrid PPP model) advocated by Moszoro (2010), the public would be able to extract maximum benefits from using PPPs compared to the traditional procurement approach. However, where such incentives are not clear, it may be difficult to extract such benefits and the PPP model may even be inferior compared to the traditional procurement approach. Without such information, it will remain difficult to determine ex-post if the original decision to use a PPP was more cost effective or not compared to the traditional alternative.

Attempts to compare projects coming from different sectors, different countries and different regions or continents may not yield accurate comparison. Therefore, the use of a hybrid PPP model is recommended because the SPV under this model achieves an optimal capital structure that lowers the overall cost of the PPP project. It is also recommended that government authorities need to improve public sector accountability on services delivered through PPP projects to avoid experiencing the same challenges faced by the South African Gauteng road improvement project and the Australian West Gate Bridge. This can be done by; (i) developing PPP frameworks that force public sector PPP implementing agencies to be transparent about their 
procurement processes, (ii) Public sector PPP implementing agencies must conduct public consultations before a PPP project is implemented. The agency should make public all relevant information to allow a proper engagement with the public on the economic rationale of implementing the project as a PPP. The public sector agency should also demonstrate that the views collected through the public consultation process were considered in the final decision to implement the project as a PPP project and (ii) setting up mechanisms for redress in cases individuals or organisations have suffered loss or damage in the process of implementing the project.

Furthermore, it is recommended that governments should always strive for optimal risk sharing between the PPP firm or concessionaire and avoid the tendency by governments of shifting project risks to the PPP firm even if those risks could be better managed by the public sector. Inappropriate risk sharing between the two parties can compromise the viability and performance of a PPP project. The hybrid PPP model is able to deal with this challenge as it strives for an optimal capital structure that takes the advantages of the two parties' strengths into account in any PPP project. It is also paramount that countries, which are planning to implement and those that have implemented a number of PPP projects, should also put in place an independent PPP Regulator that will balance the interests of the private sector party, the government and the public. The study cannot conclusively say that the PPP model is the right model for delivering public infrastructure projects, as this is depended on many factors as discussed in the paper. However, for PPPs to deliver a project to the satisfaction of the public sector or its agency, it is recommended that the public sector needs to improve transparency about PPP agreements to enhance public acceptance of PPP projects.

\section{References}

Alcazar, L., Nakasone, E. \& Torero, M. (2007). Provision of public services and welfare of the poor: Learning from an incomplete electricity privatisation process in rural Peru. Washington DC: International Food Research Institutes (IFPRI).

Allen, G. (2001). The private finance initiative (PFI). The House of Commons', Research Paper No. 01/117, December.

Bafoil, F. \& Ruiwen, L. (2010). Re-examining the role of transport infrastructure in trade, regional growth and governance: Comparing the Greater Mekong Subregion (GMS) and Central Eastern Europe (CEE). Journal of Current Southeast Asian Affairs, 2(2010), 73-119.

Binza, S. M. (2008). Public-private partnerships in metropolitan government: Perspectives on governance, value for money and the roles of selected stakeholders. Development Southern Africa, 25(3), 297-315.

Bloomfield, P. (2006). The challenging business of long-term public-private partnership: Reflections on local experience. Public Administration Review, 66(93), 400-411.

Boardman, A. E., Laurin, C., Moore, M. A. \& Vining, A. R. (2009). A cost-benefit analysis of the privatization of Canadian national railway. Canadian Public Policy-Analyse De Politiques, 35(1), 58-83.

Boopen, S. (2006). Transport infrastructure and economic growth: Evidence from Africa using dynamic panel estimates. The Empirical Economics Letters, 5(1), 37-52.

Brits, A. (2010). The financial burden of national roads infrastructure and the equity thereof: A South African perspective. Journal of Transport and Supply Chain Management, 4(1), 39-56.

Corry, D. (2004). New Labour and PPPs'. In: Ghobadian, A., Gallear, D., O’Regan, N. \& Viney, H. eds. The publicprivate partnerships: Policy and experience. London: Palgrave Macmillan Publishing, 24-36.

Currie, D. (2000). Funding the London underground, Discussion paper 35, [online]. London: London Business School, March.

De Bettignies, J. \& Ross T. W. (2004). The economics of public-private partnerships. Canadian Public PolicyAnalyse De Politique, $\mathrm{xxx}(2), 135-154$.

Domberger, S. \& Jensen, P. (1997). Contracting out by the public sector: Theory, evidence and prospects. Oxford Review of Economic Policy, 13(4), 67-78.

Domberger, S. \& Rimmer, S. (1994). Competitive tendering and contracting in the public sector: A survey. In: Grimsey, D. and Lewis, M. eds. The economics of public-private partnerships. Northampton, Massachusetts: Edward Elgar.

Dudkin, G. \& Valila, T. (2005). Transaction costs in public-private partnerships: a first look at the evidence. Economic and Financial Report 2005/3. European Investment Bank. 
Eberhard, A., Kolker, J. \& Leigland, J. (2014). South Africa's renewable energy IPP program: Success factors and lessons. Public-private infrastructure advisory facility (PPIAF). May. Washington DC. World Bank.

Engel, E., Fischer, R. \& Galetovic, A. (2013). The Basic Public Finance of Public-Private Partnerships. Journal of the European Economic Association, 11(1), 993-1020.

European Commission. (2003). Guidelines for successful public-private partnerships. Brussels: European Commission.

European Investment Bank. (2005). Evaluation of PPP projects financed by the EIB. Evaluation Report; March.

Fourie, F. \& Burger, P. (2000). An economic analysis and assessment of public-private partnerships (PPPs). The South African Journal of Economics, 68(4), 305-315.

Gabriel, S. \& Head, J. (2005). The private financing initiative: An innovative procurement tool for today's public administrators, [online]. Washington: George Washington University.

Globerman, S. \& Vining, A. R. (1996). A framework for evaluating the government contracting-out decision with an application to information technology. Public Administration Review, 56(6), 577-586.

Grimsey, D. \& Lewis, M. K. (2005). Introduction', In: Grimsey, D. and Lewis, M.K. eds. The economics of publicprivate partnerships, xiii-xl. Cheltenham: Edward Elgar.

Guash, J. L. (2004). Granting and Renegotiating Concession Contracts: Doing it right; World Bank. Washington.

Hall, D. (2015). Why public-private partnerships don't work: The many advantages of public alternatives. Public services international research unit. University of Greenwich.

Harris, C. (2003). Private participation in infrastructure in developing countries: Trends, impacts, and policy lessons. World Bank Working Paper, No.5. Washington DC. April.

International Monetary Fund. (2004). Public-private partnerships. Paper prepared by the Fiscal Affairs Department. Washington: March. Washington DC: IMF.

Ismail, Z., Mabuza, P., Pillay, K. \& Xolo, S. (2014). Infrastructure development within a regulated environment: Concern for regulators. Journal of Economic and Financial Sciences, 7(s), 69-586.

Kim, B. (2006). Infrastructure Development for the economic development in developing countries: Lessons from Korea and Japan. GSICS Working paper series, No.11. Kobe University, November.

King, P. S. (2001). Competitive tendering and contracting out: an introduction. Australian National University Canberra, ACT 0200, August.

Klein, M. (1996). Risk, taxpayers, and the role of Government in Project Finance. Policy Research Working Paper 1688. Washington DC: The World Bank Private Sector Advisory Services Department, December.

Lapre, M. A. (2003). Managing learning curves in factories by creating and transferring knowledge. California management review, 46(1).

McDavid, J. C. \& Clemens, E. G. (1995). Contracting out local government services: the B.C. experience. Canadian Public Administration, 38(2), 177-193.

Monga, A., Mahta, A. \& Ranja, S. (2009). Problems and prospects of contracting out in India. A case study, $J O A A G, 4(1), 86-97$.

Moszoro, M. (2010). Efficient public-private partnerships. Working paper WP-884. October. IESE Business School. University of Navara.

Munnell, A. H. (1992). Infrastructure investment and economic growth. The Journal of Economic Perspectives, 6(4), 189-198.

OECD. (2006). Review of the national policy, legislative and institutional environment necessary for the establishment of municipal public-private partnerships (PPPs) for public service delivery and local development in the Europe and CIS region. UNDP Capacity 2015/PPPUE-Public-private partnerships programme. March. OECD.

Quiggin, J. (1996). Private sector involvement in infrastructure projects. Australian Economic review, 96(1), 51-64, 379-386.

Republic of South Africa. National Treasury. (2004). PPP Manual Module 1: South African Regulations for PPPs. National Treasury Practice Note No. 02. Pretoria: National Treasury.

Republic of South Africa. National Treasury. (2007). Medium-Term Expenditure Framework (MTEF). Pretoria: National Treasury.

Rives. J. M. \& Heaney, M. T. (1995). Infrastructure and local economic development. Regional Science Perspectives, 25(1), 58-73. 
Sadka, E. (2007). Public private partnerships: A public economics perspective. CESifo economic studies. South African Road Agency Limited. (2012). Annual report.

Serrao, A. \& Flanagan, L. (2011). R4 billion-toll contract fury: Foreign-owned firm to profit from 'anti-people' roads. The Star. 14 February.

Snieska, V. \& Simkunaite, I. (2009). Socio-economic Impact of infrastructure investments. Economics of Engineering Decisions, (3), 16-24.

TD Economics. (2006). Creating the winning conditions for public-private partnerships (P3s) in Canada. Special Report, June.

United Kingdom, Department of International Development. (2007). Literature review on private sector infrastructure investment. Department of International Development (DFID) Working Paper No. 24, London: October.

United States of America, Department of Transportation. (2007). Case studies of transportation public-private partnerships around the world. Prepared for the office of policy and governmental affairs. Final Report, prepared by AECON consults Team, work order, 05-002, July.

Urban Land Institute. (2005). Ten principles for successful public/private partnerships. Washington DC ULI.

Vining, A. R. \& Boardman, A. E. (2006). Public-private partnerships in Canada: theory and evidence. SAUDER School of Business, UBC P3 Project. Working Paper 2006-04. December.

Vining, A. R., Boardman, A. E. \& Poschmann, F. (2004). Public-Private Partnerships in the U.S. and Canada: Case studies and lessons. International public procurement conference proceedings, 3.

Yescombe, E. R. (2007). Public-private partnerships: Principles of policy and finance. Oxford: Elsevier Ltd.

Yoshino, N. \& Nakahigashi, M. (2000). The role of infrastructure in economic development. 